\title{
Interculturality and the Political within Education
}

\section{Dervin, Fred}

Routledge

2021

Dervin , F \& Simpson, A 2021 , Interculturality and the Political within Education . Routledge

Research in Education , Routledge , Abingdon, Oxon . https://doi.org/10.4324/9780429471155

http://hdl.handle.net/10138/327980

https://doi.org/10.4324/9780429471155

Downloaded from Helda, University of Helsinki institutional repository.

This is an electronic reprint of the original article.

This reprint may differ from the original in pagination and typographic detail.

Please cite the original version. 
ROUTLEDGE FOCUS

INTERCULTURALITY AND

THE POLITICAL WITHIN

EDUCATION

Fred Dervin and Ashley Simpson

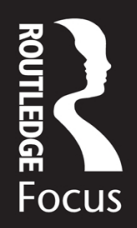




\section{Interculturality and the Political within Education}

This innovative book problematises the internal relationships within and between the intercultural and the political in education. It engages in a critical dialogue with current practices and discourses, and the focus on 'the political' offers an alternative trajectory to explore interculturality within education.

Drawing on international research and consolidated with the application of top interdisciplinary theories in the field, Dervin and Simpson alert us to the current dangers of treating interculturality loosely in education. The authors engage in a dialogue to encourage readers to examine the meaning of interculturality and the state of research in education today, suggesting that we move beyond merely rehearsing theories, concepts and methods. More importantly they urge researchers, teachers and students to question Western-centric ideologies of interculturality.

Interculturality and the Political within Education is a must read for those who are dissatisfied with current intercultural research and education. It will be of great interest to researchers and students of the philosophy of education and those interested in the contemporary debates concerning ideologies, definitions and ownership of interculturality.

Fred Dervin is Professor of Multicultural Education at the University of Helsinki, Finland. He also holds distinguished professorships in Australia, Canada, China, Luxembourg, Malaysia and Sweden.

Ashley Simpson is a Lecturer in Language Education at the University of Edinburgh, UK. 


\section{Routledge Research in Education}

This series aims to present the latest research from right across the field of education. It is not confined to any particular area or school of thought and seeks to provide coverage of a broad range of topics, theories and issues from around the world.

Recent titles in the series include

The Role of Research in Teachers' Work

Narratives of Classroom Action Research

Lesley Scanlon

Community-based Media Pedagogies

Relational Practices of Listening in the Commons

Bronwen Low, Paula M. Salvio, and Chloe Brushwood Rose

Designing for Learning in a Networked World

Edited by Nina Bonderup Dohn

Personal Narratives of Black Educational Leaders

Pathways to Academic Success

Robert T. Palmer, Mykia Olive, Joycelyn Hughes, Chase Frazer,

and Barbara Boakye

Building Trust and Resilience among Black Male High School Students

Boys to Men

Stuart Rhoden

Interculturality and the Political within Education

Fred Dervin and Ashley Simpson

For more information about this series, please visit: www.routledge.com/ Routledge-Research-in-Education/book-series/SE0393 


\title{
Interculturality and the Political within Education
}

\author{
Fred Dervin and \\ Ashley Simpson
}


First edition published 2021

by Routledge

2 Park Square, Milton Park, Abingdon, Oxon, OX14 4RN

and by Routledge

605 Third Avenue, New York, NY 10158

Routledge is an imprint of the Taylor \& Francis Group, an informa business

(C) 2021 Fred Dervin and Ashley Simpson

The right of Fred Dervin and Ashley Simpson to be identified as authors of this work has been asserted by them in accordance with sections 77 and 78 of the Copyright, Designs and Patents Act 1988.

All rights reserved. No part of this book may be reprinted or reproduced or utilised in any form or by any electronic, mechanical, or other means, now known or hereafter invented, including photocopying and recording, or in any information storage or retrieval system, without permission in writing from the publishers.

Trademark notice: Product or corporate names may be trademarks or registered trademarks, and are used only for identification and explanation without intent to infringe.

British Library Cataloguing-in-Publication Data A catalogue record for this book is available from the British Library

Library of Congress Cataloging-in-Publication Data

A catalog record for this book has been requested

ISBN: 978-1-138-59999-4 (hbk)

ISBN: 978-0-367-76767-9 (pbk)

ISBN: 978-0-429-47115-5 (ebk)

Typeset in Times New Roman

by Apex CoVantage, LLC 


\section{Contents}

Introduction 1

1 Characterising interculturality 6

2 Who was influential in the ways we understand interculturality? 30

3 How does intercultural research and education influence experiences of interculturality? 50

4 Can we prepare/get prepared for interculturality? 64

5 What is the state of research on interculturality today? 92

6 The intercultural is always ideological and political 108

$\begin{array}{ll}\text { Conclusion } & 114\end{array}$

$\begin{array}{ll}\text { Bibliography } & 121\end{array}$

Index 130 


\section{$\Longrightarrow$ Taylor \& Francis Taylor \& Francis Group http://taylorandfrancis.com}




\section{Introduction}

In Spring 1865, while visiting his family, Karl Marx filled out a questionnaire entitled Confessions, which was very popular in Victorian England. The questionnaire contained items such as "The quality you like best", "Your aversion", "Your favourite colour of eyes and hair". For the item "Your motto", he wrote down in Latin "De omnibus dubitandum" [doubt everything] (Singer, 1980: 93). This motto applies to what we are attempting to do in this book about the omnipresent, yet problematic, notion of interculturality.

Interculturality is a word of consequence, a word that matters in education, although it might be used as a mere 'stop-gap' at times.

All things 'intercultural' in research and education have spread around the world in different waves. To start with, it is important to say that the idea of interculturality is not a new 'thing'. The phenomenon and the education that goes with it (how to prepare people to meet other people) have occurred throughout history under different guises. In research and education, it found an official voice in the 20th century. In the 1950s American diplomacy led the way with the work of the anthropologist E. T. Hall who set a stepping stone by providing American diplomats with training in intercultural communication. The business world followed suit, first in the 'West'. Interculturality has become a global industry today (e.g. intercultural consultancy). Education has also witnessed some kind of 'intercultural revolution', especially since mass migration to the Western world and the increased internationalisation of higher education.

Discussions of civil rights, social justice, racism, 'clash of civilisations', orientalism, etc. over the past decades have also had to do with interculturality. We should remember, however, that although we use the word intercultural in this book, many other (similar) initiatives have emerged over the past decades, under different labels: multicultural, transcultural and the fashionable term 'global' as in 'global citizenship' and 'global competence'. 


\section{Introduction}

Things have changed over the decades, and many ideas from the past 70 years have been questioned - although they can still be identified in some books, research papers and curricula. Amongst the critiques about past perspectives on interculturality, different kinds of -isms have been under attack: Euro- and Western-centrism (the influence of Western and European ideologies on how we deal with interculturality), culturalism (culture as the explanation for everything in interculturality), essentialism (people's essence as the only explanatory force for what they do and say), East-Westism, etc. More postmodern, so-called non-essentialist, perspectives have appeared to do away with some of these issues. Some other approaches try to include voices that have been silent/silenced in intercultural scholarship and to open up dialogues about the notion of interculturality. For example, a recent textbook for English majors, published in China, promises just to do that. Written by Yuxin, J., Byram, M., Xuerui, J., Li, S. and Xuerui, J. (2019), Experiencing global intercultural communication: Preparing for a community of shared future for mankind and global citizenship attempts a pluralistic approach to 'global intercultural communication'. However, we feel that it does not do justice to real global perspectives. As such, although some elements of 'Chinese culture and philosophy' are included here and there in the book, it is hard to see how they work with the canonical 'Western' intercultural knowledge that fills the book. The imbalance between 'Western' and other knowledge is obvious for example in the collection of about 50 quotes that appear throughout Experiencing global intercultural communication. Less than five quotes are from/about China and a few quotes from other parts of the world (e.g. India and Turkey). The rest are from British and American scholars from the broad field of intercultural communication education. Ideologically, this makes such a potentially important initiative still dominated by what has been critiqued about scholarship on interculturality.

\section{Why did we write this book?}

For Althusser (1965: 67), the way we deal with a specific issue relies on a range of concepts which guide the questions we ask, and therefore the answers we provide. Our main motivation in writing this book is to send the message that we need to treat the notion of interculturality very carefully. We know this complex field very well, having been involved and engaged with top scholars and participated in many international research projects on intercultural issues. What is more, our research and teaching experiences in places like China and Russia have alerted us to the current dangers of treating interculturality loosely. What we have witnessed in these contexts is 'desperate' teachers and researchers being forced implicitly to teach about interculturality 
from American textbooks and to research the notion following e.g. American and British models of intercultural competence (a central concept in the field of interculturality). This often leads to students merely 'parroting' these theories, models, concepts and methods, without realising that they do not always make sense in their own context and in their languages. The answers they receive to their questions about interculturality are thus (wrongly) 'governed' by concepts that are provided to them in intercultural communication education. We have witnessed the same in Finland where some scholars and students rehearsed 'by rote' ideologies passed onto them by American multiculturalists such as James Banks or the European Union and the Council of Europe - two important marketers of everything 'intercultural'.

People tend to recycle, rehearse, apply, judge their students and/or research participants against these ideologies, without a hint of criticality. This is why we felt the need to examine the current situation and to launch debates concerning ideologies, definitions and ownership of interculturality. We suggest breaking the dominating habitual ways of thinking about and 'doing' interculturality but also to reconfigure current 'critical' discussions of the notion (to which e.g. Fred has contributed in the past, see Dervin, 2016).

\section{Book structure}

Amongst the six chapters that compose the book, five were written in the form of dialogues. We wanted our readers to witness the way scholars unthink concepts, notions, epistemologies, methods and assumptions related to interculturality and renegotiate them together. Each chapter corresponds to a question about interculturality: (Chapter 1) What to make of the notion of interculturality? (Chapter 2) Who was influential in the ways we understand interculturality? (Chapter 3) How does intercultural research and education influence experiences of interculturality? (Chapter 4) Can we prepare/get prepared for interculturality? (Chapter 5) What is the state of research on interculturality today? We each take the floor to provide answers and then explore our differences and similarities. We also ask questions to the reader at the end of each chapter. The final chapter entitled "The intercultural is always ideological and political" is a response to a response to one of our critical articles about a reference framework of interculturality disguised under the label of 'democratic culture', produced by a European team led by two white British 'native speakers' of English. We use this chapter as a concrete illustration of how the political (and ideologies of not being ideological about interculturality) and interculturality are enmeshed in education. The conclusion to the book offers a clear and succinct summary of what to take away from this book and covers three aspects that we feel are essential: conceptualising, researching and preparing for interculturality. 


\section{Working method}

Our working principles are as follow:

1. Systematically, we examine the 'travel' of the words that are used in English and other languages to deal with interculturality. There is a tendency to use notions and concepts in English without questioning their meanings in this global language - and other languages - as if words were just mere equivalents. We argue that this increases the gap between the powerful voices that impose them and the voiceless who just have to accept them and use them to survive if they wish to e.g. publish in international journals ('governed' by the powerful voices) and/or to be allowed to speak at international conferences. In their volume entitled Words in Motion, Gluck and Lowenhaupt Tsing (2009: 11) maintain:

Words stabilize our understanding. They allow us to insert ourselves into discourses, institutions, and social relations. ... Our focus is how words and worlds are made at different scales, ranging from particular class niches and political campaigns to transnational realignments of culture and power. This task involves watching words move across space and time.

Take for example the simple word of $a$ thing in English. According to Merriam-Webster (www.merriam-webster.com/dictionary/thing), a thing is "1. an object or entity not precisely designated or capable of being designated use this thing; 2 . an inanimate object distinguished from a living being". When we are taught to write, we are asked not to use this "nothing word' since it is not exact enough and has no 'being'. Interestingly, in the Chinese language, a thing translates as 东西, which refers to East and West. In this language, a thing is thought of in terms of relations and movement between these two positions, rather than hinting at the not-being. This might have an influence on the way different people see their relation to the word and to the realities this very word represents.

In the book, we include archaeologies, discussions of untranslatable words as much as possible to emphasise the need to be critical of recycling words from English. This will allow us to become aware of the ideologies that such words impose on the users and listeners. This will also allow us to revise some notions and assumptions related to interculturality.

2. Our book relies on genuine interdisciplinarity. Dealing with interculturality requires awareness and use of updated knowledge from other fields of scholarship. Too often in education, old-fashioned terms, rejected in the field where they originally appeared, are used to look into certain phenomena. We must do an archeology of all the concepts that we use in the field of 
interculturality and look for alternative ways of thinking about it. By doing so, we can rewrite our imaginations about interculturality. In this book, we use knowledge from philosophy, sociology, anthropology, psychology and cultural studies (amongst others). Input from literature, the graphic arts, the performing arts and music also enrich our discussions. We believe that it is only through such interdisciplinary engagement that interculturality can be problematised. We should not create boundaries between the different fields of knowledge and the arts since they all can contribute to renewing the notion.

3. Having had the opportunity to explore the way interculturality is taught and researched in different parts of the world, we note that the overall emphasis is still on individuals interacting with each other, with an exclusive focus on each of these individuals. As such, their relations or what they do and co-construct together are rarely taken into account - all seems to relate to the 'self'. For example, those researching the concept of intercultural competence will tend to 'test', 'analyse', 'observe', 'report on' one interactant's skills, ignoring the fact that their skills relate to a specific context and to the interlocutors' identity, behaviours and intertextuality (e.g. how much they remind them of another social being). Even more important, the influence of research, (global) administration, (global) politics, the economy and the media on how people interact with each other, what they (don't) say or do, is systematically ignored to focus on e.g. stereotyping, individual racism and discrimination. In this book, we open up these discussions to include all these aspects in the way we problematise interculturality.

We hope that this book highlights the urgency to revise our often simplistic or mechanic ways of thinking about interculturality and that it can lead to changes in the way the notion is used around the world. There is a need to make the notion more intercultural itself by including alternative voices about it. An increased awareness of the economic and political determinants of intercultural knowledge and practice in education is also crucial more than ever. 


\section{References}

Ackrill, J. L. (Ed.). (1987). A new Aristotle reader. Oxford \& Princeton: Princeton University Press.

Aduba, U. (2014). Never thought about changing her Nigerian name. Retrieved from www.colorlines.com/articles/uzo-aduba-never-thought-about-changing-hernigerian-name

Agamben, G. (2020). Clarifications. Retrieved September 20, 2020 from

www.journal-psychoanalysis.eu/coronavirus-and-philosophers/

Althusser, L. (1965). Pour Marx. Paris: Frandis Maspero.

Althusser, L. (2001). Lenin and philosophy and other essays. New York: Monthly Review Press.

Althusser, L. (2011). Philosophy and the spontaneous philosophy of the scientists \& other essays. London: Verso.

Althusser, L. (2017). How to be a Marxist in philosophy. London: Bloomsbury Academic.

Angermuller, J. (2014). Poststructuralist discourse analysis: Subjectivity in enunciative pragmatics. Hampshire: Palgrave Macmillan.

Anholt, S. (2009). Places: Identity, image and reputation. Hampshire: Palgrave Macmillan.

Aronczyk, M. (2013). Branding the nation: The global business of national identity. Oxford: Oxford University Press.

Bakhtin, M. M. (1981). The dialogic imagination: Four essays (ed. M. Holquist , trans. C. Emerson \& M. Holquist ). Austin: University of Texas Press.

Bakhtin, M. M. (1984). Problems of Dostoevskyslpoetics (ed. \& trans. C. Emerson ). Austin: University of Texas Press.

Bakhtin, M. M. (1990). Art and answerability: Early philosophical essays (eds. M. Holquist \& V. Liapunov ). Austin, University of Texas Press.

Bakhtin, M. M. (2012). Sobranie sochinenij. (T.3). Teoriia romana (1930प961 gg.)

(eds. S. G. Bocharov \& Vadim Valeraanovich Kozhinov ). Moskva: Jazyki

slavianskikh kultur.

Balandier, G. (1980). Le pouvoir sur sches. Paris: Ballard.

Balibar, E. (2005). Difference, otherness, exclusion. Parallax, 11(1), $19 B 4$.

Barbot, M. , \& Dervin, F. (2011). Rencontres interculturelles et formation dossier.

đucation permanente.

122 Barthes, R. (2012). Travels in China. Cambridge: Polity Press.

Bauman, Z. (1997). Postmodernity and its discontents. London: Polity Press.

Bauman, Z. (2004). Identity: Conversations with Benedetto Vecchi. Cambridge:

Polity Press.

Baumann, G. (1996). Contesting culture: Discourses of identity in multi-ethnic

London. Cambridge: Cambridge University Press.

Bayart, J. (2005). The illusion of cultural identity. London: C. Hurst \& Co.

Bennett, M. (1986). A developmental approach to training for intercultural

sensitivity. International Journal of Intercultural Relations, 10(2), $179 \mathbb{1 9 5 .}$

Bensa, A. (2010). AprBLLV-Strauss pour une anthropologie thaille humaine. Paris:

di. Textuel.

Benvenuto, S. (2020). Welcome to seclusion. Retrieved September 20, 2020 from www.journal-psychoanalysis.eu/coronavirus-and-philosophers/

Berdyaev, N. (1960). The destiny of man. New York: Harper.

Berdyaev, N. (1962). Truth and revelation. New York: Collier Books.

Bergson, H. (1911). Laughter: An essay on the meaning of the comic. KDenhavn:

Green Integer.

Bergson, H. (1946). The creative mind. New York: Philosophical Library.

Bergson, H. (2002). Key writings. London: Bloomsbury Academic.

Billetier, J.-F. (n.d.). Interpreting China for the WestJean Frandis Billeter. Retrieved

September 18, 2020 from www.youtube.com/watch?v=cthAXVJuu_Y

Boulez, P. (1996). Conversations with Boulez: Thoughts on conducting. Bradford:

Amadeus Press. 
Bouveresse, J. (2008). La connaissance de ICrivain: Sur la littॄature, la vait\& la vie. Marseille: Agone.

Breidenbach, J. , \& Ny氏 P. (2005). China inside out contemporary Chinese nationalism and transnationalism. Budapest, Hungary \& New York, NY: Central European University Press.

Byram, M. (1997). Teaching and assessing intercultural communicative competence. Bristol: Multilingual Matters.

Byram, M. (2020). The responsibilities of language teachers when teaching intercultural competence and citizenship: An essay. China Media Research, 16(2), 7784.

Cage, J. , \& Goldberg, J. (1976). John Cage: Interviewed by Jeff Goldberg. The Transatlantic Review, 55/56, 103 II10.

Cassin, B. (2016). Translation as paradigm for human sciences. The Journal of Speculative Philosophy, 30(3), 242266. doi:10.5325/jspecphil.30.3.0242

Chauvier, $\square(2017)$. Anthropologie de IDrdinaire: Une conversion du regard.

Toulouse: Anarchasis.

Cheng, A. (2014). Histoire de la pensel chinoise. Paris: dl Points.

Cheng, A. (2016). La Chine, ternelle Autredle IEurope? [video]. Retrieved from www.youtube.com/watch?v=LxIFtN9HcWM\&t=2939s

Christie, A. (1923). The murder on the links. London: Penguin Classics.

Cioran, $\square$ (1985). Drawn and quartered. New York: Seaver Books.

Council of Europe . (2018a). Reference framework for democratic culture: Volume one: Contexts, concepts and model. Strasbourg: Council of Europe Publishing. 123 Council of Europe . (2018b). Reference framework for democratic culture: Volume two: Descriptors of competences for democratic culture. Strasbourg: Council of Europe Publishing.

Council of Europe . (2018c). Reference framework for democratic culture: Volume three: Guidance for implementation. Strasbourg: Council of Europe Publishing.

Dabashi, H. (2015). Can non-Europeans think? London: Zed Books.

Deleuze, G. (1990). The logic of sense (trans. M. Lester \& C. Stivale ). London:

Athlone.

Deleuze, G. (1994). Difference and repetition. New York: Columbia University

Press.

Deleuze, G. (1995). Negotiations, 1972[1990. New York: Columbia University

Press.

Deleuze, G. , \& Guattari, F. (1980). A thousand plateaus: Capitalism and schizophrenia (trans. B. Massumi ). Minneapolis: University of Minnesota Press. Demoule, J.-P. (2017). Mais o Sont passElles Indo-Europens? Le mythe dørigine de IOccident. Paris: Points.

Dervin, F. (2011). A plea for change in research on intercultural discourses: A Iiquidapproach to the study of the acculturation of Chinese students. Journal of Multicultural Discourses, 6(1), 3752.

https://doi.org/10.1080/17447143.2010.532218

Dervin, F. (2013). La meilleure ducation au monde? Paris: L日armattan.

Dervin, F. (2016a). Interculturality in education: A theoretical and methodological toolbox. London: Palgrave Macmillan.

Dervin, F. (2016b). Is the emperor naked? Experiencing the BISA hysteria $\square$ branding and education export in Finnish academia. In Trimmer, K. (Ed.), Political pressures on educational and social research: International perspectives (pp.

7793). London: Routledge.

Dervin, F. (2019a). पIBeijing: MoveableType.

Dervin, F. (2020). Creating and combining models of intercultural competence for teacher education/training: On the need to rethink IC frequently. In Dervin, F. , Moloney, R. , \& Simpson, A. (Eds.), Intercultural competence in the work of teachers: Confronting ideologies and practices (pp. 5772). Abingdon, Oxon: Routledge.

Dervin, F. , \& Auger, N. (Eds.). (2012). Pour une didactique des imaginaires dans lenseignement-apprentissage des langues trangres. Paris: LBarmattan. 
Dervin, F. , Chen, N. , Yuan, M. , Sude , \& Jacobsson, A. (2020). COVID-19 and interculturality: First lessons for teacher educators. Education and Society, 38(1), 89I06.https://doi.org/10.7459/es/38.1.06

Dervin, F. , Gajardo, A. , \& Lavanchy, A. (2013). Politics of interculturality.

Newcastle: Cambridge Scholars.

Dervin, F. , \& Jacobsson, A. (2020). Teacher education for critical and reflexive interculturality. London: Palgrave Macmillan.

Dervin, F. , \& Machart, R. (2015). Cultural essentialism in intercultural relations.

London, UK: Palgrave Macmillan.

Dervin, F. , \& Machart, R. (2017). Intercultural communication with China: Beyond (reverse) essentialism and culturalism? Singapore: Springer.

124 Dervin, F. , \& Simpson, A. (2019). Transnational edu-business in China: A case study of culturalist market-making from Finland. Frontiers of Education in China, 14(1), 3358. https://doi.org/10.1007/s11516-019-0002-z

Diderot, D. (1773/2014). The paradox of the actor. Ulsan: University of Ulsan

Press.

Dobzhansky, T. (1950). The genetic basis of evolution. Scientific American, 182(1), 32411.

Dostoevsky, F. (2001). The idiot. New York: Vintage Books.

Ducrot, O. (2018). Dire et ne pas dire: Principes de smantique linguistique. Paris: Hermann.

Dwivedi, D. , \& Mohan, S. (2020). The community of the forsaken: A response to Agamben and Nancy. Retrieved September 20, 2020 from www.journal-

psychoanalysis.eu/on-pandemics-nancy-esposito-nancy/

Eriksen, T. H. (2001a). Between universalism and relativism: A critique of the UNESCO concept of culture. Culture and Rights, $127 \mathbb{1 4} 8$.

doi:10.1017/cbo9780511804687.008

Eriksen, T. H. (2001b). Small places, large issues: An introduction to social and cultural anthropology. London: Pluto Press.

Esposito, R. (2008). Bios: Biopolitics and philosophy. Minneapolis: University of Minnesota Press.

Esposito, R. (2009). Communitas: The origin and destiny of community (trans. T. Campbell ). Stamford: Stamford University Press.

Esposito, R. (2012). The third person: Politics of life and philosophy of the impersonal (trans. Z. Hanafi ). London: Polity Press.

Esposito, R. (2017). The origin of the political: Hannah Arendt or Simone Weil? New York: Fordham University Press.

Esposito, R. (2020). Vitam instituere. Retrieved September 20, 2020 from www.journal-psychoanalysis.eu/vitam-instituere/

Etymonline.com . (2020). Respect. Retrieved September 20, 2020 from www.etymonline.com/search?q=respect

Fang, W. (2019). Modern notions of civilization and culture in China. Beijing:

Springer.

Farber, P. L. (2016). Dobzhansky and Montagusdebate on race: The aftermath. Journal of the History of Biology, 49(4), 625639.

Fitzpatrick, F. (2017). Taking the Culture Dut of Culture shockDA critical review of literature on cross-cultural adjustment in international relocation. Critical

Perspectives on International Business, 13(4), 278296.

https://doi.org/10.1108/cpoib-01-2017-0008

Flaubert, G. (1989). A sentimental education: The story of a young man. Oxford: Oxford University Press.

Foucault, M. (1997). The politics of truth. New York: Semiotext.

Gannett, L. (2013). Theodosius Dobzhansky and the genetic race concept. Studies in History and Philosophy of Science Part C: Studies in History and Philosophy of Biological and Biomedical Sciences, 44(3), 250261.

Gaultier, J. de. (1902). Bovarysme. Paris: Mercure de France.

Gillespie, A. (2006). Becoming other: From social interaction to self-reflection.

Greenwich: IAP-Information Age Publ. 
125 Gluck, C. , \& Lowenhaupt Tsing, A. (Eds.). (2009). Words in motion: Toward a global lexicon. Durham \& London: Duke University Press.

Goldstein, H. (2004). International comparisons of student attainment: Some issues arising from the PISA study. Assessment in Education: Principles, Policy and Practice, 11, 319B30.

Goodrich, P. (1997). Hermes and institutional structures: An essay on dogmatic communication. In Goodrich, P. (Ed.), Law and the unconscious: Language, discourse, society (pp. 137匹63). London: Palgrave Macmillan.

Goody, J. (2006). The theft of history. Cambridge: Cambridge University Press. Grek, S. (2009). Governing by numbers: The PISA effect in Europe. Journal of Education Policy, 24(1), 23B17. doi:10.1080/02680930802412669

Guo, X. (2008). A concise Chinese-English dictionary for lovers. London: Vintage Books.

Guo, X. (2020). A lover巨ddiscourse. London: Vintage.

Hall, E. T. (1959). The silent language. New York: Anchor Books.

Hall, E. T. , \& Trager, G. L. (1953). The analysis of culture. New York: American Council of Learned Societies.

Hannerz, U. (1996). Transnational connections: Culture, people, places. London: Routledge.

Hansen, M. H. , \& Svarverud, R. (Eds.). (2010). iChina: The rise of the individual in modern Chinese society. Copenhagen: NIAS Press.

Hansen, V. (2020). The year 1000: When explorers connected the world and globalization began. New York: Scribner.

Hinrichsen, J. , Lange, J. , \& Reichel, R. (Eds.). (2020). Diversities: Theories \& practices: Festschrift for Reinhard Johler. TDingen: Untersuchungen des LudwigUhland-Instituts der UniversitUTbingen.

Hofstede, G. (1983). National cultures in four dimensions: A research-based theory of cultural differences among nations. International Studies of Management \& Organization, 13(12), 4674.

Holliday, A. , Hyde, M. , \& Kullman, J. (2010). Intercultural communication: An advanced resource book for students. London: Routledge.

Horvat, S. (2019). Poetry from the future: Why a global liberation movement is our civilisations last chance. London: Penguin Classics.

Hui, T. , \& Dervin, F. (forthcoming). Cfeel somehow, all as human, we are all the same $\square$ Students perception and construction of interculturality in China. Journal of Bilingual Education and Bilingualism.

Jank区itch, V. , \& Berlowitz, B. (1978). Quelque part dans Inachev Paris:

Gallimard.

Kerbrat-Orecchioni, C. (2014). Løonciation: De la subjectivit ¿lans le langage. Paris: Armand Colin.

Kliger, I. (2008). Heroic aesthetics and modernist critique: Extrapolations from

Bakhtinslauthor and hero in aesthetic activity. Slavic Review, 67(3), 551566.

Kraus, K. (2014). In these great times. Amsterdam: November Editions.

Laing, R. D. (1969). The divided self: A study of sanity and madness. London:

Tavistock.

Lakoff, R. (1992). Talking power: The politics of language. New York: Basic Books. Lao, S. (1929). Mr ma \& son. London: Penguin Classics.

126 Lao, S. (2014). Mr Ma and son. London: Penguin Classics.

Lavanchy, A. , Gajardo, A. , \& Dervin, F. (2014). Anthropologies de Interculturalit $\square$ Paris: LBarmattan.

Leeds-Hurwitz, W. (2014). Intercultural dialogue. Key Concepts in Intercultural Dialogue, 1. Retrieved from

https://centerforinterculturaldialogue.files.wordpress.com/2014/02/key-conceptintercultural-dialogue1.pdf

Lefort, C. (2007). Complications: Communism and the dilemmas of democracy. New York: Columbia University Press.

LVnas, E. (1985). Ethics and infinity. Karnataka: Claretian Publications. 
Lewis, R. (2004). Finland, cultural Lone Wolf. Boston, MA: Nicholas Brealey

Publishing.

Ling, Z. (2020). एbrigine. Retrieved from www.enfantdimmigres.fr

Linhart, D. (2015). La comđle humaine du travail: De la d\$̧umanisation taylorienne

Tha sur-humanisation managriale. Toulouse: 传

Løhrot, E. (1894). Kalevala. Helsinki: Suomalaisen kirjallisuuden seuran

kirjapainossa.

LukCs, G. (2010). Soul and form. New York: Columbia University Press.

Machart, R. , Dervin, F. , \& Gao, M. (2016). Intercultural masquerade: New

orientalism, new occidentalism, old exoticism. Heidelberg: Springer.

Maffesoli, M. (1996). The time of the tribes. London: Sage.

Maffesoli, M. (2020). La crise du coronavirus ou le grand retour du tragique [The coronavirus crisis or the return of the tragic]. Le Figaro, March 23. Retrieved from www.lefigaro.fr/vox/societe/michel-maffesoli-la-crise-du-coronavirus-oule-grandretour-du-tragique-20200323

Malraux, A. (1967). Antimemoirs. London: Hamish Hamilton.

Mantel, H. (2009). The way to glory. London Review of Books, 10(5). Retrieved from www.Irb.co.uk/the-paper/v10/n05/hilary-mantel/the-way-to-glory

Markova, I. , Linell, P. , Grossen, M. , \& Salazar Orvig, A. (2007). Dialogue in focus groups: Exploring socially shared knowledge. London: Equinox Publishing.

Marnette, S. (2005). Speech and thought presentation in French: Concepts and strategies. Amsterdam: John Benjamins Publishing.

Mok, E. (2020). What would you say I am? From The Rooftops: A Showcase of

East Asian Talent, July 17. Retrieved from

https://readingfringefestival.co.uk/whatson/from-the-rooftops-a-showcase-of-east-

asian-talent/

Mouffe, C. (2005). On the political. London: Routledge.

Mouffe, C. (2013). Agonistics: Thinking the world politically. London: Verso.

Musil, R. (1994). Precision and soul: Essays and addresses. Chicago: University of

Chicago Press.

Musil, R. (1996). The man without qualities. New York: Vintage Books.

Nancy, J. L. (1991). The inoperative community. Minneapolis: University of

Minnesota Press.

Nelson, E. S. (2019). Chinese and buddhist philosophy in early twentieth-century german thought. London: Bloomsbury Academic.

Niemi, H. , Toom, A. , \& Kallioniemi, A. (2016). Miracle of education: The principles and practices of teaching and learning in Finnish schools. Rotterdam: Sense.

127 Ogay, T. , \& Edelmann, D. (2016). Tlaking culture seriously inter-cultural education and training. European Journal of Teacher Education, 39(3), 388400. doi:10.1080/02619768.2016.1157160

Paveau, M. (2006). Les prđiscours. S.I.: Presses Sorbonne Nouvelle.

Perkins, F. (2004). Leibniz and China: A commerce of light. Cambridge: Cambridge University Press.

Phillips, A. (2007). Multiculturalism without culture. Princeton, NJ: Princeton

University Press.

Pieterse, J. N. (2004). Globalization and culture: Global mange. Lanham, MD:

Rowman \& Littlefield.

Piller, I. (2010). Intercultural communication. Edinburgh: Edinburgh University

Press.

Popper, K. (2002). Unended quest: An intellectual autobiography. London:

Routledge.

Qu, W. (2020). Can Chinasldistinctive academic niches go to the world?

Contemporary Foreign Language Research. Retrieved from

https://mp.weixin.qq.com/s/61dul86LBebN6n_X-pY-Gw

$\mathrm{R}$ boul, $\mathrm{H}$. (forthcoming). Postcolonial interventions in intercultural communication

knowledge: Meta-intercultural ontologies, decolonial knowledges and

epistemological polylogue. Journal of International and Intercultural

Communication. 
Rendall, S. (2014). Culture. In Cassin, B. , Apter, E. , Lezra, J. , \& Wood, M. (Eds.), Dictionary of untranslatables: A philosophical lexicon (p. 191). Princeton, $\mathrm{NJ}$ :

Princeton University Press.

Riitaoja, A.-L. , \& Dervin, F. (2014). Interreligious dialogue in schools: Beyond asymmetry and categorisation? Language and Intercultural Communication, 14(1), 7690. doi:10.1080/14708477.2013.866125

Ronchi, R. (2020). The virtues of the virus. Retrieved September 20, 2020 from www.journal-psychoanalysis.eu/on-pandemics-nancy-esposito-nancy/

Roucek, J. S. (1944). A history of the concept of ideology. Journal of the History of Ideas, 5(4), 479488. doi:10.2307/2707082

Roulet, E. (1991). LArticulation du discours en franals contemporain. Berne: P. Lang.

Sahlberg, P. (2011). Finnish lessons: What can the world learn from educational change in Finland? New York: Teachers College Press.

Said, E. W. (1996). Representations of the intellectual: The 1993 Reith lectures. New York: Vintage Books.

Salinger, J. D. (1958). The catcher in the rye. Harmondsworth: Penguin Books in association with Hamish Hamilton.

Sartre, J. (1964). Being and nothingness: An essay in phenomenological ontology. New York: Citadel Press.

Sen, A. (2007). Identity and violence: The illusion of destiny. London: Penguin Classics.

Sidorkin, A. M. (1999). Beyond discourse: Education, the self, and dialogue. New York: SUNY Press.

Simpson, A. , Chen, N. , \& Dervin, F. (2019). Finnish professors[experiences of decolonisation and internationalisation in South African universities. Education and Society, 37(2), 524. Retrieved from

www.ingentaconnect.com/contentone/jnp/es/2019/00000037/00000002/art00002

128 Simpson, A. , \& Dervin, F. (2019a). The Council of Europe Reference

Framework of Competences for Democratic Culture: Ideological refractions, othering and obedient politics. Intercultural Communication Education, 2(3), 102正9. https://doi.org/10.29140/ice.v2n3.168

Simpson, A. , \& Dervin, F. (2019b). Forms of dialogism in the Council of Europe Reference Framework on Competences for Democratic Culture. Journal of Multilingual and Multicultural Development, 41(4), 305319.

Simpson, A. , \& Dervin, F. (2019c). Global and intercultural competences for whom? By whom? For what purpose?: An example from the Asia society and the OECD. Compare: A Journal of Comparative and International Education, 49(4), 672677. https://dx.doi.org/10.1080/03057925.2019.1586194

Simpson, A. , \& Dervin, F. (2019d). पПत(1), 1430.

Singer, P. (1980). Marx: A very short introduction. Oxford: Oxford University Press. Solovyov, V. S. (1965). Foundations of theoretical philosophy (trans. V. Tolley \& J. P. Scanlan ). Chicago: University of Chicago Press.

Stasavage, D. (2020). The decline and rise of democracy: A global history from antiquity to today. Princeton, NJ: Princeton University Press.

St de Exupry, A. (1943/1971). The little prince. San Diego, USA: Harcourt, Brace and World, Inc.

Stiegler, B. (2015). States of shock: Stupidity and knowledge in the twenty-first century. Cambridge: Polity Press.

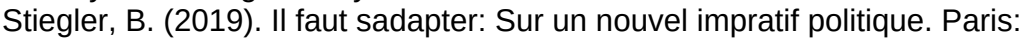
Gallimard.

Subrahmanyam, S. (2011). Three ways to be Alien. Hanover: Brandeis University Press.

Sude Yuan, M. , \& Dervin, F. (2020). Introduction to ethnic minority education in China: Policies and practices. Frankfurt: Springer-Verlag Berlin An.

Sue, D. W. (2010). Microaggressions in everyday life: Race, gender, and sexual orientation. Hoboken, NJ: John Wiley and Sons. 
Vally, P. (1943). Tel quel. Paris: Gallimard.

Vally, P. (1958). The art of poetry. London: Routledge and Paul.

Vasylchenko, A. (2014a). Postupok. In Cassin, B. , Apter, E. , Lezra, J. , \& Wood, M. (Eds.), Dictionary of untranslatables: A philosophical lexicon (pp. 811812).

Princeton: Princeton University Press.

Vasylchenko, A. (2014b). Svoboda. In Cassin, B. , Apter, E. , Lezra, J. , \& Wood, M. (Eds.), Dictionary of untranslatables: A philosophical lexicon (pp. 1105108).

Princeton: Princeton University Press.

Vasylchenko, A. (2014c). Istina. In Cassin, B. , Apter, E. , Lezra, J. , \& Wood, M. (Eds.), Dictionary of untranslatables: A philosophical lexicon (pp. 513515).

Princeton: Princeton University Press.

Voloshinov, V. N. (1973a). Marxism and the philosophy of language (trans. I. R.

Titunik \& L. Matejka ). Cambridge: Harvard University Press.

Voloshinov, V. N. (1973b). Marxism and the philosophy of language (trans. L.

Mate-jka \& I. R. Titunik ). New York: Seminar Press.

129 Weber, M. (1949). The methodology of the social sciences. New York: The

Free Press of Glencoe.

Wikan, U. (2002). Generous betrayal: Politics of culture in the new Europe.

Chicago: University of Chicago Press.

Xiao, Q. (2010). Traveller without a map. Nanjing: Jiangsu Literature and Art

Publishing House.

Yuan, M. , Sude , \& Tao, J. (2019). П]10, 102[08.

Yuan, M. , Sude, Wang, T. , Zhang, W. , Chen, N. , Simpson, A. , \& Dervin, F. (2020). Chinese Minzu education in higher education: An inspiration for Western $\square$ diversity education? British Journal of Educational Studies, 68(4), 461486.

doi:10.1080/00071005.2020.1712323

Yuxin, J. , Byram, M. , Xuerui, J. , Li, S. , and Xuerui, J. (2019). Experiencing global intercultural communication: Preparing for a community of shared future for mankind and global citizenship. Beijing: BFSU Press.

Zhuangzi . (2013). The complete works of Zhuangzi. New York: Columbia University Press. 